\title{
Drinking up the Amazon
}

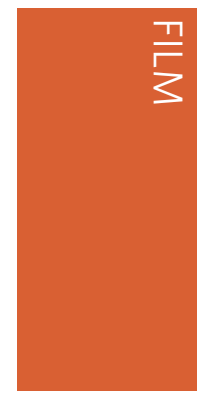

Slovenian-born Martin Strel is 53 , overweight and a heavy drinker. He is also an incredibly accomplished long-distance swimmer. In 2000 he swam the Danube, in 2002 the Mississippi and in 2004 the frighteningly polluted Yangtze River, where the water was so toxic his blood had to

be tested daily.

In Big River Man, Martin attempts to swim the entire length of the Amazon. It's a daunting task - given that the river is home to crocodiles, piranhas and creatures that like to bury themselves in human orifices - but his motivations are noble. According to his son, the narrator and Martin's voice for interviews and this film, Martin wants to raise awareness of the lack of clean water around the world, and to "wake people up to the destruction of the rainforest". Unfortunately, the opening scenes of Martin - who happens to be sponsored by a major car company - speeding around Slovenia drunk and glued to his mobile phone, don't quite resonate with the environmental theme.

Nevertheless, he wants to do it. And after months of preparation - reduced to footage of him playing in his favourite water park, attending local festivities and generally being quirky - he arrives in the small town of
Atalaya in Peru. Here, at the source of the Amazon, he wades into the murky water for the first time. Crowds cheer, the river looms; the enormity of the task is palpable.

But the excitement soon fades, and within days of the start, Martin is 'falling apart'. He has second degree burns from the sun, his blood pressure is dangerously high and he is at serious risk of a stroke. He insists on drinking whisky instead of water; the situation deteriorates.

\section{It's a daunting task - given \\ that the river is home to \\ crocodiles, piranhas and \\ creatures that like to bury \\ themselves in human orifices.}

By the time he's reached halfway, he is experiencing hallucinations, hearing voices in his head and has entirely retreated into his own world. The doctor attributes his behaviour to a subcutaneous blood infection in the brain.

Martin's team, essentially a couple of doctors and Matt - a professional gambler come navigator and drinking companion - show little support. The doctor smiles as she announces that Martin is heading for a stroke. And Matt, who has a strong tendency to hero-worship, grows

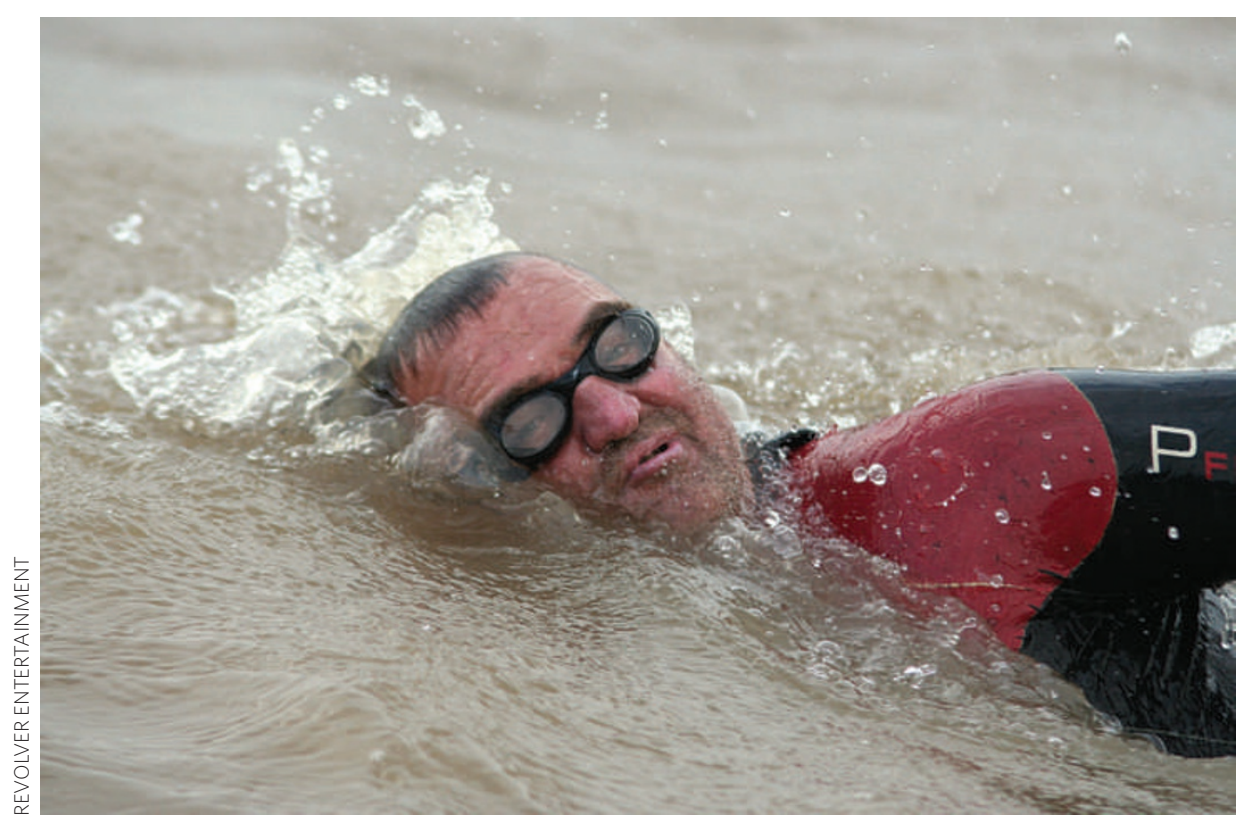

increasingly euphoric with every stroke Martin takes away from reality, and enters into great reveries about how Martin "is giving hope to people all over the world". At one point he likens him to Jesus.

Equally lacking in empathy is the narration, which provides little insight into Martin and his journey. And the heavyhanded attempts to mirror Martin's mental state with music - violent orchestral excerpts interspersed with drumming and electric guitars - coupled with psychotic switching between scenes detracts entirely from his raw experience. But there are moments when the viewer and Martin collide head on.

One night, well into the journey, Martin and Matt - equally at odds with reality by now - disappear off into the darkness. The next morning they are found naked, on a beach, completely changed. In a state of absorption, Martin explores an uprooted tree, and Matt crawls beneath a log. Both are completely silent. The peacefulness of the scene is utterly compelling.

Although all the ingredients for a fascinating film or great reality TV programme are here - mental deterioration, alcoholism, the Amazon - the film fails to engage and excite. And the viewer leaves with absolutely no idea of who Martin is, or what it was really like to swim the Amazon. This is mainly due to the son's tireless narration, which interrupts and distorts what could have been an amazing observational piece.

As for the plight of the Amazon, we are fed the occasional fact about the rate at which the rainforest is being destroyed to make way for cattle farms, and the poverty of its people. But the dry, monotonous way in which these sound bites are delivered make the whole environmental plight seem like a last minute add-on, and certainly not the central motivation of Martin's quest.

Back in their home country, Martin's son digs out a speech he prepared in the final days of the trip. Intended to be a statement to the world, it was left unread because of problems with Martin's health. The son is sad because he feels that a big moment was missed; an apposite summary of how the viewer might feel at the end of this film. 